\title{
CHANGES IN PLANT SPECIES COMPOSITION \\ IN ABANDONED AND RESTORED LIMESTONE GRASSLANDS - THE EFFECTS OF TREE AND SHRUB CUTTING
}

\author{
ZBigniEW DZWONKO, STEFANIA LOSTER \\ Institute of Botany, Jagiellonian University \\ Lubicz 46, 31-512 Kraków, Poland \\ e-mail ubdzwonk@cyf-kr.edu.pl
}

(Received: November 15, 2006. Accepted: February 23, 2007)

\begin{abstract}
Abandoned semi-natural limestone grasslands are often overgrown by shrubs and trees. Little is know if and to what extant xerothermic limestone grasslands can be restored by tree cutting. This was tested in a 12-year experiment after the clearing of a 35-year-old secondary pine wood developed on unmanaged grassland in the close proximity of not overgrown old grassland. After 12 years, there were no significant differences in the number of field layer species on the plots in the old and restored grasslands. But over this period the number of meadow species increased in all sites, while the number of xerothermic calcareous species increased significantly only in the old grassland plots. The developing shrub layer negatively influenced the number of nitrophilous and ruderal species in grasslands restored in the former close and open woods, and the number of all species, including the number of non-tufted perennials and perennials with vegetative spread, in the former open wood. The number of meadow species increased in years with higher precipitation in late spring and early summer. The obtained results suggest that in overgrowing grasslands shrubs and trees should be cut every few years, before their covers increase to about $30 \%$. However, this treatment alone will not stop the changes to communities with dominance of tall and vegetatively spreading grasses and forbs. Cutting trees and shrubs in sites where most grassland species have already vanished, without additional managements supporting their dispersal, seedling recruitment and development, is not sufficient to restore limestone grasslands rich in xerothermic species.
\end{abstract}

KEY WORDS: permanent plots; restoration; secondary succession; Southern Poland; species diversity; time series.

\section{INTRODUCTION}

The remnants of semi-natural limestone grasslands are characteristic elements of the agricultural landscape in the hilly regions of southern Poland. These are composed of species-rich and geographically differentiated communities. Many grassland species reached this area in long time as migratory waves from the southeast and south of Europe (Medwecka-Kornaś and Kornaś 1966; Michalik and Zarzycki 1995). For several centuries, the grasslands on limestone hill slopes were regularly grazed, most often by sheeps and goats and their development and maintenance was primarily linked with this type of land use. During the two decades after World War II, the traditional methods of management had been discontinued and most of the limestone grasslands abandoned. Today, remnants of these grasslands, ranging from several dozen square metres to several hectares, are isolated by fields and meadows. The distances between them are from several hundred metres to several kilometres. Only some of abandoned limestone grasslands have been set aside as nature reserves.
Various studies have pointed out that most of the grassland species have poor dispersal ability and cannot, without grazing animals acting as dispersal vectors, re-colonize isolated grasslands nor colonize isolated open sites (Gibson et al. 1987; Kollman and Poschlod 1997; Poschlod and Bonn 1998; Poschlod et al. 1998). The above cited studies showed that herbivores moving between grasslands could disperse enormous numbers of seeds during a year. Species-rich grasslands cannot be restored from seed bank because relatively few species of these communities form persistent seed banks in the soil (Dutoit and Alard 1995; Milberg 1995; Bekker et al. 1997; Davies and Waite 1998; Willems and Bik 1998; Stampfli and Zeiter 1999). Experimental studies suggest that even though the seeds of grassland species do occur in seed rain or soil seed bank, successful restoration of species-rich grasslands may still require additional management such as grazing or mowing in order to facilitate the development of suitable species seedlings (Hutchings and Booth 1996).

The remnants of old grasslands in southern Poland like in other parts of central, western and northern Europe are 
therefore, the only refuges for many grassland and xerothermic species of plants and small animals (Mortimer et al. 1998; Dolek and Geyer 2002; van Swaay 2002; WaallisDe Vries et al. 2002). Thus, maintaining grassland communities is of utmost importance to the conservation of local and regional biodiversity.

Unmanaged grasslands have changed as a result of secondary succession and are often overgrown by shrubs and trees. An increase in tree and shrub cover results in a decrease in the number and cover of grassland species and may lead to their local extinction within decades. Rejmánek and Rosén (1992), found a strong decline in the number of grassland species in alvar grassland overgrown by Juniperus communis, when the shrub cover exceeded $75 \%$. Willems and Bik (1998) noted a remarkable reduction in the number of species in limestone grassland overgrown by Crataegus monogyna, as early as 20 years after abandonment. According to Fischer and Stöcklin (1997) and Stöcklin and Fischer (1999) even in extensively used isolated limestone grasslands, the most vulnerable to local extinction are small plant populations, species with short life cycle, species with high habitat specificity and species with shorter-lived seeds.

In many cases periodic cutting of trees and shrubs is the only available conservation management aimed at preservation or regeneration of grassland vegetation. Experiments carried out in overgrown limestone grasslands have proven that, as a rule, the number of species increases quickly in several years after cutting the trees and shrubs (Rosén 1988; Zobel et al. 1996; Dzwonko and Loster 1998; Pärtel et al. 1998; Willems and Bik 1998; Barbaro et al. 2001). However, little is known if and to what extant xerothermic limestone grasslands can be restored by tree cutting. In this study we present results of a twelve year-long restoration experiment. The aim is to assess the possibility of the long-term maintenance of limestone grassland community in places with slow and relatively fast temporal changes in cover of shrub layer.

\section{MATERIALS AND METHODS}

\section{Study site}

The study was carried out in the Skołczanka reserve (36 ha; $50^{\circ} 01^{\prime} \mathrm{N}, 19^{\circ} 50^{\prime} \mathrm{E}$ ), situated in southern Poland, some $8 \mathrm{~km}$ southwest of Kraków. In this area the mean annual temperature is $8.1^{\circ} \mathrm{C}$, and the mean temperatures in January and July are $3.1^{\circ} \mathrm{C}$ and $18.5^{\circ} \mathrm{C}$, respectively. The mean annual precipitation is $665 \mathrm{~mm}$. The reserve includes a Jurassic limestone hill elevated $275 \mathrm{~m}$ a.s.1. As late as in the 1940s and 1950s, the grassland covering most of the hill was grazed by domestic animals. After the reserve was established in 1957, trees and shrubs have begun to colonize the grassland. The main species growing on this abandoned grassland was Pinus sylvestris. Over the period between 1957 and 1988 grassland area decreased from 33 to $11 \%$ of the reserve area. The remnants of old grassland represented the Koelerio-Festucetum association with such characteristic species as Festuca rupicola, Koeleria macrantha and Phleum phleoides. More details of the vegetation in the reserve and the direction and rate of secondary succession are given by Dzwonko and Loster (1990, 1992, 1998).
The experiment with tree and shrub cutting was carried out in an area of 0.5 ha, on a west-facing slope, with a 20 $\mathrm{m}$ difference in elevation. In 1957 only scattered small plants of woody species grew in the grassland, whereas in 1992 the area was covered by a 35-year-old pine wood with a well-developed shrub layer. The secondary wood consisted of a mosaic of strongly shaded places and small gaps. In the wood gaps xerothermic calcareous and meadow species still occurred, whereas at sites with a closed tree canopy grassland species did not grow.

\section{Data collection and analysis}

In the winter of 1992 all trees and shrubs were felled in the study area, and in the spring 35 permanent plots, $5 \times 5 \mathrm{~m}$, were established systematically at $5 \mathrm{~m}$ distances, in four rows $12 \mathrm{~m}$ apart, throughout the cleared wood and the adjoining old abandoned grassland, not yet overgrown. The three longest rows were $96 \mathrm{~m}$ in length. 15 plots were located in the former closed wood site, 12 in the former wood gaps, and 8 in the old grassland. From 1992 to 2003, the percentage cover (at 10\% estimation intervals) of vascular plant species, and that of shrub and field layers were estimated in each plot at the end of June or in July. The same records were also used to assess the response of various plant functional groups and types to temporal changes in cover of shrub layer (Dzwonko and Loster 2007). The nomenclature of plant species is that used in Flora Europaea by Tutin et al. (1964-1980).

The cover of shrubs in the formerly wooded site increased gradually. After ten years, the shrub layer cover in the plots on the former wood gaps varied from 5 to $70 \%$, whereas in the plots on the former closed wood site ranged from 15 to $85 \%$. At that time the shrub layer was most often composed of Crataegus spp., Quercus robur, Rosa spp. Cornus sanguinea, Prunus spinosa, Frangula alnus and Rubus caesius. Since this layer was rather dense in the most of study plots, in the early spring of 2002, all trees and shrubs, which grew in the site of wood felled in 1992, were cut again.

Numbers of xerothermic calcareous, meadow, sandy and heathland, woodland, and nitrophilous and ruderal species were calculated for all records. Species were attributed to habitats according to Oberdorfer et al. (1990) and Ellenberg et al. (1991), i.e. they were divided into the classes Festuco-Brometea (xerothermic calcareous species), SedoScleranthetea and Nardo-Callunetea (sandy and heathland species), Molinio-Arrhenatheretea (meadow species), Querco-Fagetea and Vaccinio-Piceetea, including several others closely associated with the woodland habitats (woodland species), and Artemisietea, Plantaginetea, Epilobietea and Secalietea (nitrophilous and ruderal species). Five species groups with various growth forms and vegetative reproduction were distinguished: annual and biennials, non-tufted perennials without runners or rhizomes, tufted perennials, perennials with short runners or rhizomes and perennials with long runners or rhizomes. In order to characterize the environmental preferences of the species composing the study grasslands in successive years, mean characteristic Ellenberg indicator values were calculated $(\mathrm{L}-$ light, $\mathrm{M}$ - moisture, $\mathrm{R}$ - reaction, $\mathrm{N}$ - nitrogen; Ellenberg et al. 1991) using number of species.

Canonical Correspondence Analysis (CCA; CANOCO program; Ter Braak and Šmilauer 1998) with time as a constraining variable was used to assess the significance 
of changes in species composition and cover during 10 and 12 years (from 1992 to 2003) in the study sites. Monte Carlo permutation test under the reduced model with the splitplot design option was done in each case. As the analyses covered from 8 to 15 time series to avoid problems with autocorrelation, restricted permutations were applied. 999 permutations restricted to the cyclic shifts within time series were carried out. The total changes in community compositions were characterized by the length of gradient for the first axis of Detrended Canonical Correspondence Analysis (DCCA) with detrending by segments and time as variable. CCA with three dummy explanatory variables (former closed wood, former open wood, and old grassland) was applied to determine differences in species composition and cover between plots in three sites in successive years (from 1992 to 2003). In this case only two first CCA axes were constrained. In order to characterize differences between sites, Euclidean distances between centroids of plot groups defined by explanatory variables were calculated in two dimensional space, formed by the first and second CCA axes with scaling of ordination scores for inter-sample distances. Monte Carlo test with 999 permutations was used to determine significance of these axes. If successional convergence occurs the distances between the centroids should decrease with time.

Changes in number of species of different groups in the restored and old grasslands during 1992-2003 in relation to time and cover of shrub layer were analysed using multiple linear regression. For every group regressions of the species number with time and cover of shrubs as continuous explanatory variables and plots as dummy explanatory variables were calculated. The variables plots accounted for the differences among plots. The significance of regression coefficients was evaluated using permutation testing in order to avoid assumptions of normal data distribution. Problems with autocorrelation in time series were avoided by applying restricted permutations. The multiple regression analyses were performed using program CANOCO. The test under full model with 999 permutations restricted to dependent (across sites) cyclic shifts within time series was used. For estimating the differences between numbers of species of given group in the study sites the KruskalWallis test and multiple comparison according to Conover (Theodorsson-Norheim 1986) were employed.

\section{RESULTS}

\section{Temporal and spatial variation in community composition}

CCA with the Monte Carlo permutation test revealed significant changes in species composition and cover in the restored and old grasslands during 12 years, but in the case of species composition in the old grassland only at $P=0.07$ (Table 1). The comparison of gradient lengths along the first DCCA axes shows that the greatest changes in species cover occurred in the site of the former closed wood, lesser changes in the former open wood, and the least - in the old grassland. Over 12 years, on the plots in all three sites, the average number of persistent herb species was almost the same. However, on the plots in the former closed wood a significantly higher number of transient species occurred than on the plots in the former open wood and old grassland (Table 2). Despite cutting shrubs and trees twice, the number of persistent tree and shrub species was significantly higher on the plots in restored grasslands, compared with the old grassland.

The results of CCA for the same years showed that after 12 years the three compared sites differed significantly in the species composition and cover (Table 3 ). This is visualized by a biplot based on CCA for 2003 with sites as variables and scaling of ordination scores for inter-species distances (Fig. 1). The first axis arranges species relative to their cover in the old grassland and in the grassland restored in the former closed wood, and the second axis relative to the grassland in the former open wood. The species located on a line joining two centroids were present only in the sites represented by these centroids, while the species that are close to the particular centroid were absent or very rare in other sites. According to CCA for species cover the distances between centroids for plots in various sites decreased considerably during the 12 years, as did the characteristics of the fit, i.e. percentage of the variability explained

TABLE 1. Results of the CCA with time as a constraining variable. Eigenvalue $\left(\lambda_{1}\right)$ corresponds to the first CCA axis. $r$ indicates species-environment correlations. $P$ denotes the probability of changes in species composition and cover in the old and restored grassland plots. Gradient length corresponds to the first DCCA axis.

\begin{tabular}{|c|c|c|c|c|}
\hline & $\lambda_{1}$ & $r$ & $P$ & Gradient length \\
\hline \multicolumn{5}{|c|}{ Cover of species in all layers (1992-2001) } \\
\hline Old grassland & 0.08 & 0.92 & 0.044 & 0.92 \\
\hline \multicolumn{5}{|l|}{ Restored grasslands } \\
\hline in open wood & 0.17 & 0.83 & 0.035 & 1.38 \\
\hline in closed wood & 0.19 & 0.89 & 0.045 & 1.52 \\
\hline Old grassland & 0.09 & 0.93 & 0.038 & 0.96 \\
\hline \multicolumn{5}{|l|}{ Restored grasslands } \\
\hline in open wood & 0.10 & 0.82 & 0.047 & 1.02 \\
\hline in closed wood & 0.13 & 0.85 & 0.036 & 1.19 \\
\hline \multicolumn{5}{|c|}{ Presence/absence of species in the field layer (1992-2003) } \\
\hline Old grassland & 0.09 & 0.94 & 0.069 & 1.02 \\
\hline in open wood & 0.08 & 0.81 & 0.047 & 0.96 \\
\hline in closed wood & 0.08 & 0.87 & 0.038 & 0.94 \\
\hline
\end{tabular}


TABLE 2. Species turnover in the plots during 1992-2003. Values are mean species numbers. Ranges of species numbers are given in parentheses. Persistent species: present from 1992 to 2003 . Extinct species: present in 1992 and extinct before 2003. Immigrant species: absent in 1992 but later appearing and present until 2003. Extinct/immigrant species: present in 1992 later extinct and appearing and present in 2003. Transient species: absent in 1992 later appearing and extinct before 2003. $P$ denotes the probability of no difference (Kruskal-Wallis test). Within a row, values with the same letter are not significantly different at $P>0.05$, based on the Conover test.

\begin{tabular}{|c|c|c|c|c|}
\hline & \multirow{2}{*}{ Old grassland } & \multicolumn{2}{|c|}{ Restored grasslands } & \multirow{2}{*}{$P$} \\
\hline & & in open wood & in closed wood & \\
\hline Number of plots & 8 & 12 & 15 & \\
\hline \multicolumn{5}{|l|}{ Trees and shrubs } \\
\hline Persistent species & $1.5(0-4)$ & $3.4(1-6)$ & $5.2(3-8)$ & $<0.001$ \\
\hline Extinct species & $0.9^{\mathrm{A}}(0-2)$ & $0.9^{\mathrm{A}}(0-3)$ & $2.4(0-5)$ & $<0.05$ \\
\hline Immigrant species & $1.5(0-4)$ & $2.8(0-6)$ & $3.5(1-8)$ & NS \\
\hline Extinct/immigrant species & $0.2^{\mathrm{A}}(0-1)$ & $0.6^{\mathrm{AB}}(0-2)$ & $1.1^{\mathrm{B}}(0-2)$ & $<0.05$ \\
\hline Transient species & $0.5(0-3)$ & $1.4^{\mathrm{A}}(0-5)$ & $1.5^{\mathrm{A}}(0-4)$ & $<0.05$ \\
\hline \multicolumn{5}{|l|}{ Herbaceous species } \\
\hline Persistent species & $13.1(13-20)$ & $13.3(8-16)$ & $12.3(3-16)$ & NS \\
\hline Extinct species & $4.7(2-9)$ & $6.2(1-12)$ & $8.1(2-14)$ & NS \\
\hline Immigrant species & $13.1(9-18)$ & $11.6(8-18)$ & $13.0(6-16)$ & NS \\
\hline Extinct/immigrant species & $4.0(0-8)$ & $4.5(1-7)$ & $3.4(0-6)$ & NS \\
\hline
\end{tabular}

TABLE 3. Results of CCA analyses with sites as constraining variables. Herbaceous species occurring in at least $20 \%$ of the plots in one site in particular year were taken into consideration. Explained variance is variability in species data explained by the variables sites. First two CCA axes (canonical) explained $100 \%$ of variance of fitted species data. $F$ is the value of $F$-statistic for the two canonical axes. In all cases these axes were significant at $P \leq 0.001$.

\begin{tabular}{|c|c|c|c|c|c|c|c|c|c|c|c|}
\hline \multirow{3}{*}{ Year } & \multirow{3}{*}{$\begin{array}{c}\text { Number } \\
\text { of } \\
\text { species }\end{array}$} & \multirow{3}{*}{$\begin{array}{c}\text { Explained } \\
\text { variance } \\
(\%)\end{array}$} & \multicolumn{4}{|c|}{ Presence/absence of species } & \multirow{3}{*}{$\begin{array}{c}\text { Explained } \\
\text { variance } \\
(\%)\end{array}$} & \multicolumn{3}{|c|}{ Cover of species } & \multirow{3}{*}{$F$} \\
\hline & & & \multicolumn{3}{|c|}{ Distances between centroids } & \multirow{2}{*}{$F$} & & \multicolumn{3}{|c|}{ Distances between centroids } & \\
\hline & & & $\begin{array}{l}\text { Old grassl. } \\
\text { closed wood }\end{array}$ & $\begin{array}{l}\text { Old grassl. } \\
\text { open wood }\end{array}$ & $\begin{array}{c}\text { Closed wood } \\
\text { open wood }\end{array}$ & & & $\begin{array}{l}\text { Old grassl. } \\
\text { closed wood }\end{array}$ & $\begin{array}{l}\text { Old grassl. } \\
\text { open wood }\end{array}$ & $\begin{array}{c}\text { Closed wood } \\
\text { open wood }\end{array}$ & \\
\hline 1992 & 58 & 23.3 & 1.35 & 1.04 & 0.93 & 4.87 & 32.1 & 1.71 & 1.40 & 1.15 & 7.55 \\
\hline 1993 & 72 & 23.0 & 1.28 & 0.99 & 0.92 & 4.78 & 34.5 & 1.74 & 1.47 & 1.22 & 8.43 \\
\hline 1995 & 62 & 20.8 & 1.09 & 0.93 & 0.84 & 4.19 & 34.9 & 1.65 & 1.41 & 1.05 & 8.59 \\
\hline 1997 & 70 & 19.9 & 1.10 & 0.97 & 0.82 & 3.97 & 29.2 & 1.53 & 1.28 & 0.99 & 6.60 \\
\hline 1999 & 70 & 19.1 & 1.07 & 0.99 & 0.82 & 3.77 & 25.4 & 1.44 & 1.22 & 1.02 & 5.45 \\
\hline 2001 & 58 & 22.0 & 1.05 & 0.90 & 0.76 & 4.52 & 19.8 & 1.18 & 0.98 & 0.90 & 3.95 \\
\hline 2003 & 67 & 20.2 & 1.10 & 0.99 & 0.74 & 4.05 & 14.6 & 1.23 & 1.07 & 0.87 & 2.74 \\
\hline
\end{tabular}

by the variables sites and F-statistic. All this signifies a marked increase of similarity in the species cover between compared grasslands. During this time, the similarity in species composition changed much less. This similarity increased markedly only during the first three years of the experiment (Table 3). Throughout the period of observation, the least differences in the species composition and cover were between the communities in the former closed and open wood sites.

\section{Changes in vegetation characteristics}

After 12 years there were no significant differences in the number of field layer species on the plots in the compared sites. However, in the restored grasslands the numbers of xerothermic calcareous and heathland and sandy species were significantly lower than in the old grassland (Table 4). On the other hand, in the old grassland and that in the former wood gaps, the number of meadow species was significantly higher, whereas the numbers of nitrophilous and ruderal, and woodland species were significantly lower than in the grassland in the former closed wood.

Over the study period, the number of species in field layer increased significantly only in the old grassland and in the grassland restored in the former wood gaps. But in the latter case it was considerably negatively influenced by the developing shrub layer (Table 4). During 12 years, the number of meadow species increased in all sites, but the number of xerothermic calcareous species increased only in the old grassland. Over that period in the former wood sites the number of ruderal and nitrophilous species decreased; it was also negatively influenced by cover of shrubs. In the old grassland and that restored in the former wood gaps, the numbers tufted and of non-tufted perennials, and perennials with short and long vegetative spread increased notably, whereas in the former closed wood only the number of perennials with long vegetative spread increased significantly. In both restored grasslands, the number of annual and biennial species decreased and was negatively related to the shrub layer cover. In the former wood gaps the development of the shrub layer negatively affected also the number of non-tufted perennials and perennials with vegetative spread.

In the course of succession in the old grassland, the number of species of different environmental preferences changed. Here the mean indicator values for moisture and nitrogen increased, whereas the indicator values for light decrea- 


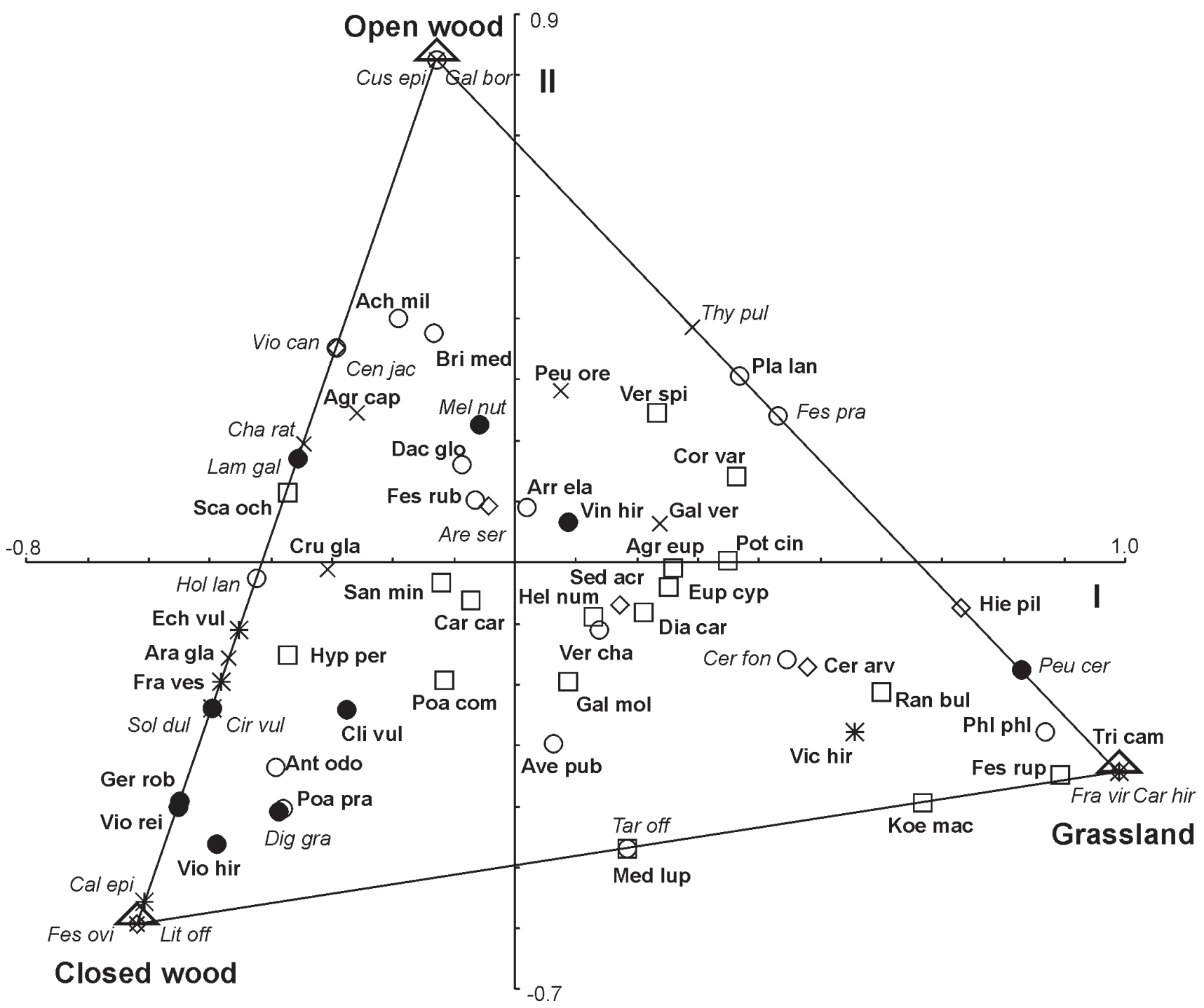

Fig. 1. Biplot of herbaceous species and centroids of sites $(\triangle)$ on the first two CCA axes $\left(\lambda_{1}=0.23, \lambda_{2}=0.13\right)$ for the plots in the old grassland (Grassland) and in the grasslands restored in the former open and closed woods (Open and closed wood, respectively) for year 2003. Species occurring in at least 20\% of the plots in one site were taken into consideration. The names of species occurring in at least $50 \%$ of the plots in one site are in bold. The diagram accounts for $14.6 \%$ and $100 \%$ of variance of species cover data and fitted species data, respectively. Symbols represent different species groups: xerothermic calcareous species $(\square)$, meadow species $(\bigcirc)$, heathland and sandy grassland species $(\diamond)$, nitrophilous and ruderal species (*⿻), woodland species $(\bigcirc)$, other species ( $\times$ ). Species abbreviations are based on the three letters of the genus and species: Achillea millefolium, Agrimonia eupatoria, Agrostis capillaris, Anthoxanthum odoratum, Arabis glabra, Arenaria serpyllifolia, Arrhenatherum elatius, Avenula pubescens, Briza media, Calamagrostis epigejos, Carex caryophyllea, C. hirta, Centaurea jacea, Cerastium arvense, $C$. fontanum ssp. triviale, Chamaecytisus ratisbonensis, Cirsium vulgare, Clinopodium vulgare, Coronilla varia, Cruciata glabra, Cuscuta epithymum, Dactylis glomerata, Dianthus carthusianorum, Digitalis grandiflora, Echium vulgare, Euphorbia cyparissias, Festuca ovina, F. pratensis, F. rubra, F. rupicola, Fragaria vesca, F. viridis, Galium boreale, G. mollugo, G. verum, Geranium robertianum, Helianthemum nummularium, Hieracium pilosella, Holcus lanatus, Hypericum perforatum, Koeleria macrantha, Lamiastrum galeobdolon, Lithospermum officinale, Medicago lupulina, Melica nutans, Peucedanum cervaria, P. oreoselinum, Phleum phleoides, Plantago lanceolata, Poa compressa, P. pratensis, Potentilla cinerea, Ranunculus bulbosus, Sanguisorba minor, Scabiosa ochroleuca, Sedum acre, Solanum dulcamara, Taraxacum officinale, Thymus pulegioides, Trifolium campestre, Veronica chamaedrys, Veronica spicata, Vicia hirsuta, Vincetoxicum hirundinaria, Viola canina, V. hirta, V. reichenbachiana.

sed. The latter slightly decreased with time also in the restored grasslands. In these grasslands the mean indicator values for reaction increased with the increased shrub cover.

Comparison of the numbers and cover of species in the field layer on the restored grassland plots in successive years revealed that they changed substantially before the second cut of shrubs in 2002 (Fig. 2). The greatest number of species in both restored grasslands was in 1997, 5 years after the first tree and shrub cutting, and it began to decrease gradually from the next year, when the mean cover of shrub layer increased to $29.7 \%$ and $31.5 \%$, respectively, in the former open and closed wood sites. It concerned above all xerothermic calcareous species and nitrophilous and ruderal species. The number of meadow species increased in 1997 and did not change markedly in the next years. The greatest cover of species in the restored grasslands was in 1995, 3 years after tree cutting, and it decreased gradually in the next years. In the former open wood site this concerned mainly meadow species, while in the former closed wood site first of all - xerothermic calcareous species. The cover of these species groups began to decrease when the mean cover of shrub layer increased to $14.8 \%$ in the former wood gaps, and to $17.8 \%$ in the former closed wood site. At the same time the cover of nitrophilous and ruderal spe- 


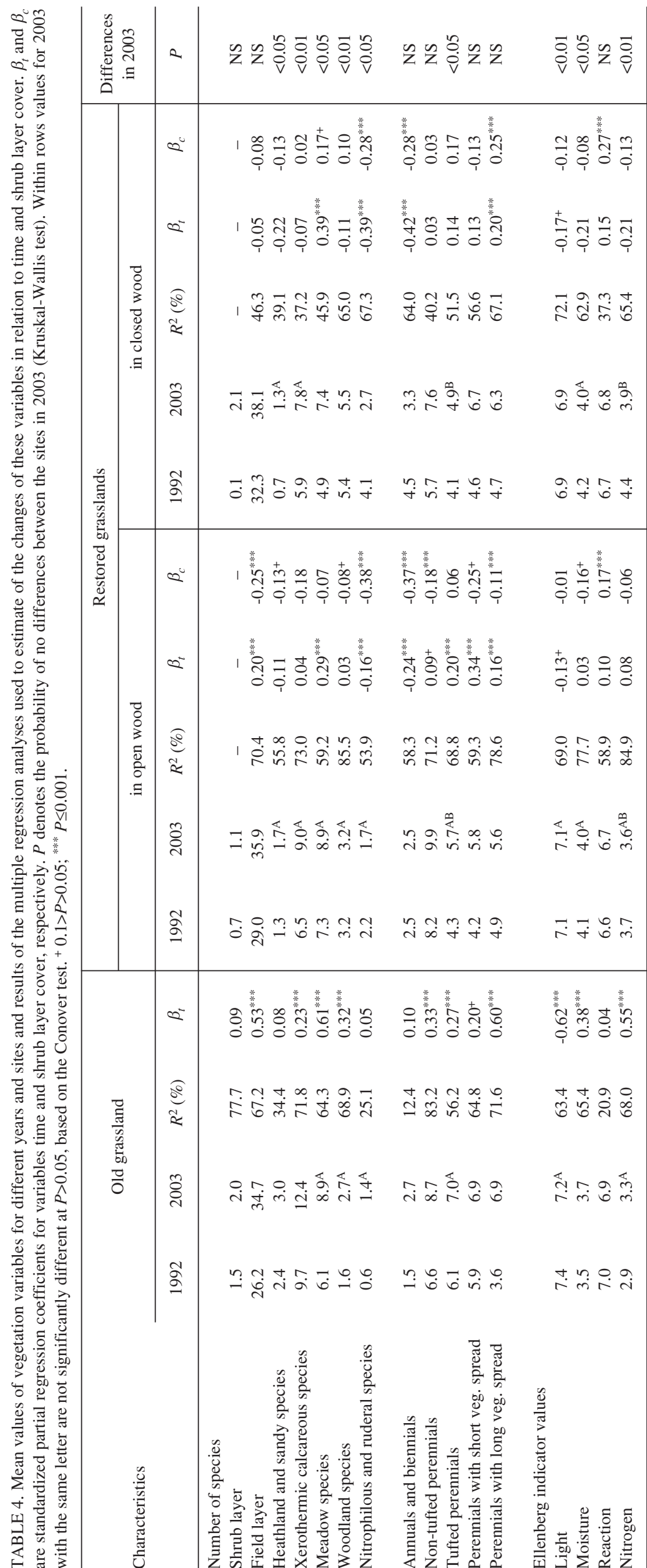

cies did not change distinctly, but the cover of woodland species increased considerably. These observations suggest that in order to maintain the species richness in the restored grasslands when woody species tend to overgrow them, and especially to preserve as many as possible xerothermic calcareous species, developing shrubs and trees should be cut not rarer then every five or six years.

\section{DISCUSSION}

During 12 years the composition and cover of species considerably changed in all the study grasslands. At that time, the similarity among them in the species cover increased. This may suggests that the development of vegetation in compared sites tends slowly towards one community. However, despite the very close proximity of the old grassland, after 12 years, the species composition of restored grasslands significantly differed from it, and was much determined by the initial conditions. The number and cover of xerothermic calcareous species did not increase in the restored grasslands and were still significantly lower than in the old grassland. Many of these species, such as Coronilla varia, Dianthus carthusianorum, Festuca rupicola, Koeleria macrantha, Potentilla cinerea and Veronica spicata, were rarer or had a lover cover, particularly in the former closed wood site, than in the old grassland. In the former wood sites the woodland species survived that had earlier colonised the secondary woods, e.g. Geranium robertianum, Lamiastrum galeobdolon, Solanum dulcamara and Viola reichenbachiana. Here still present were also some of the ruderal and nitrophilous species, e.g. Calamagrostis epigejos, Cirsium vulgare, Echium vulgare, and Fragaria vesca.

In practice, cutting trees and shrubs in sites when most grassland species have already vanished, without additional management, such as grazing, mowing, formation of gaps or even sowing seeds is not sufficient to restore limestone grasslands rich in xerothermic species, though old grassland is in closed vicinity. Various experiments have shown that the limited availability of seeds is the principal reason for the weak regeneration of grasslands. The dispersal of most grassland species is limited to several metres or even to several dozen centimetres (Verkaar et al. 1983; Stampfli and Zeiter 1999; Kalamees and Zobel 2002). When seeds are available, the low success of recruitment is often caused by the lack of suitable microsites. Seed germination and establishment of grassland species are strongly inhibited by litter, seed predation, seedling herbivory and by competition from established plants (van Tooren 1988; Rusch 

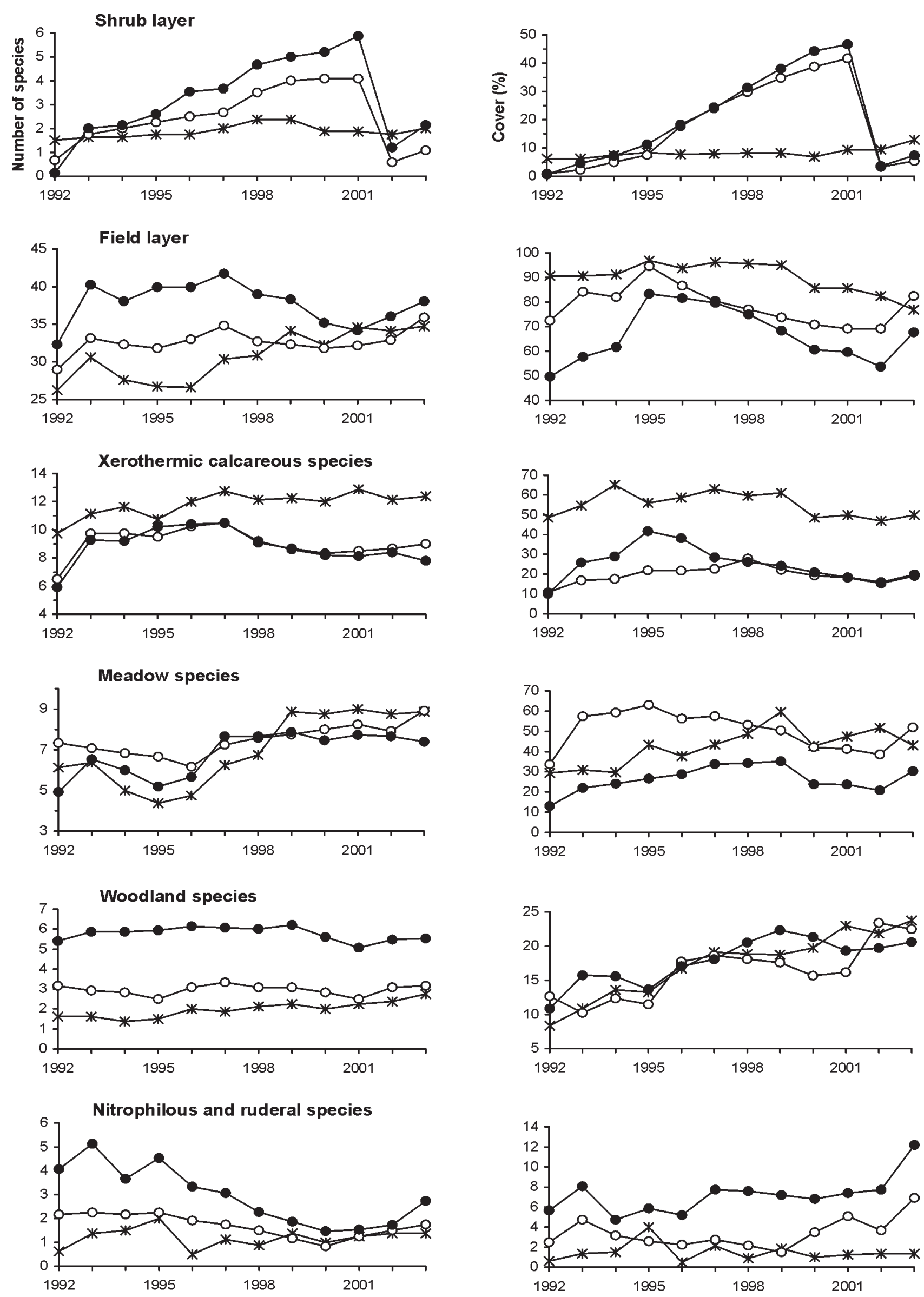

Fig. 2. Mean number and cover of species in shrub layer and different species groups in field layer in the plots on the old grassland (*) and on the grasslands restored in the former open $(\bigcirc)$ and closed $(\mathbf{O})$ woods, during 1992-2003. 
and Fernández-Palacios 1995; Stampfli and Zeiter 1999; Kupferschmid et al. 2000; Zobel et al. 2000).

Our results agree with earlier studies implying that in contrast to the initial colonisation of new sites, where stochastic processes are more important and species life-history traits are of little importance, later spread of species in developing grasslands strongly depend upon their life-history traits and becomes a function of time and management (cf. Gibson and Brown 1991a, b). In the former closed wood site the number of perennials with long vegetative spread increased at the expense of annuals and biennials during 12 years. In the former wood gaps, where some grassland species have been present from the beginning, an increase in the number of all perennial growth forms was noted, like in the old grassland. The increase in the abundance of species with extended vegetative spread has been observed in various successional series (Prach and Pyšek 1994; Jensen and Schrautzer 1999; Kahmen and Poschlod 2004). In later successional stages these species have a greater chance of penetrating into more closed vegetation cover when establishment from seeds becomes limited by a dense and compact litter layer.

In the course of succession in the old grassland the cover of taller grasses and forbs (e.g. Arrhenatherum elatius, Euphorbia cyparissias, Galium mollugo and Vincetoxicum hirundinaria) increased remarkably. Similar changes, usually with decrease in species diversity, have been observed in abandoned limestone grasslands (Willems 1983; Ward and Jenings 1990; Willems et al. 1993; Mitchley and Willems 1995). In our study, however, the average number of species per plot has increased over 12 years. Perhaps that period was too short for reduction in the overall number of species due to competition of tall species.

During the study period the shrub layer cover increased only slightly in the old grassland. A thick litter layer and dense vegetation impeded seed germination and seedling development of trees and shrubs. Thus, the impact of these species on the grassland vegetation was slight and the succession to wood very slow, although the woodland herb species cover increased. In restored grasslands, the quickly developing shrub layer affected significantly the cover and composition of field layer vegetation, particularly in the former wood gap site. With the increased shrub cover, in both restored grasslands, the number of annuals and biennials decreased. In the former wood gaps also the number of non-tufted perennials and perennials with vegetative spread decreased. This indicates that the shrub layer inhibited the development of both early successional species and some perennials occurring in established grasslands.

Analysis of changes in the species number of different species groups revealed that also weather considerably influenced species composition of the study grasslands. The number of all species in the old grassland and the number of meadow species in the old and restored grasslands were markedly lower over the period between 1992 and 1996 than in 1998-2003 (cf Fig. 2). In the former period the increase in the number of xerothermic calcareous species was observed. In the restored grasslands the number of meadow species was higher in the last 7 years of observation, despite significant increase of the shrub layer cover. These changes were clearly related to temporal variation in rainfall in late spring and early summer. In the rather dry period between 1992 and 1996 the mean sum of precipitation from May to July was $182 \mathrm{~mm}$. In the very wet year 1997, precipitation during mentioned months was 479 mm, and between 1998 and 2003 mean sum of precipitation was $283 \mathrm{~mm}$.

Experiments in lowland limestone grasslands have shown that species richness and plant cover significantly increased in plots receiving supplementary summer rainfall (Sternberg et al. 1999; Grime et al. 2000). Also long-term observations have indicated that summer rainfall is an important factor in controlling directly and indirectly species richness and composition of grassland and meadow communities (Silvertown et al. 1994; Rosén 1995; Dunnett et al. 1998). Wetter conditions during summer promote growth of perennial grasses, which tend to close the sward (Sternberg et al. 1999; Morecroft et al. 2004). Thereby they can inhibit the establishment of later successional species. This was observed in the study old grassland.

Our results suggest that shrubs and trees should be cut every few years, before their cover increased to about $30 \%$. Periodical tree and shrub cutting can, for a longer time, maintain species-rich grassland-scrub vegetation with many grassland species, and to preserve local species diversity. However, this treatment alone will not stop the changes to communities with the dominance of tall and vegetatively spreading grasses and forbs.

\section{ACKNOWLEDGEMENTS}

We thank S. Gawroński for assistance with field work.

\section{LITERATURE CITED}

BARBARO L., DUTOIT T., COZIC P. 2001. A six-year experimental restoration of biodiversity by shrub-clearing and grazing in calcareous grasslands of the French Prealps. Biodivers. Conserv. 10: 119-135.

BEKKER R.M., VERWEIJ G.L., SMITH R.E.N., REINE R., BAKKER J.P., SCHNEIDER S. 1997. Soil seed banks in European grasslands: does land use affect regeneration perspectives? J. Appl. Ecol. 34: 1293-1310.

DAVIES A., WAITE S. 1998. The persistence of calcareous grassland species in the soil seed bank under developing and established scrub. Plant Ecol. 136: 27-39.

DOLEK M., GEYER A. 2002. Conserving biodiversity on calcareous grasslands in the Franconian Jura by grazing: a comprehensive approach. Biol. Conserv. 104: 351-360.

DUNNETT N.P., WILLIS A.J., HUNT R., GRIME J.P. 1998. A 38-year study of relations between weather and vegetation dynamics in road verges near Bibury, Gloucestershire. J. Ecol. 86: 610-623.

DUTOIT T., ALARD D. 1995. Permanent seed banks in chalk grassland under various management regimes: their role in the restoration of species-rich plant communities. Biodivers. Conserv. 4: 939-950.

DZWONKO Z., LOSTER S. 1990. Vegetation differentiation and secondary succession on a limestone hill in southern Poland. J. Veg. Sci. 1: 615-622.

DZWONKO Z., LOSTER S. 1992. Species richness and seed dispersal to secondary woods in southern Poland. J. Biogeogr. 19: 195-204.

DZWONKO Z., LOSTER S. 1998. Dynamics of species richness and composition in a limestone grassland restored after tree cutting. J. Veg. Sci. 9: 387-394.

DZWONKO Z., LOSTER S. 2007. A functional analysis of vegetation dynamics in abandoned and restored limestone grasslands. J. Veg. Sci. 18: 203-212.

ELLENBERG H., WEBER H.E., DÜLL R., VOLKMAR W., WERNER W., PAULIßEN D. 1991. Zeigerwerte von Pflanzen in Mitteleuropa. Scripta Geobot. 18: 3-248. 
FISCHER M., STÖCKLIN J. 1997. Local extinctions of plants in remnants of extensively used calcareous grasslands 19501985. Conserv. Biol. 11: 727-737.

GIBSON C.W.D., BROWN V.K. 1991a. The effects of grazing on local colonization and extinction during early succession. J. Veg. Sci. 2: 291-300.

GIBSON C.W.D., BROWN V.K. 1991b. The nature and rate of development of calcareous grassland in southern Britain. Biol. Conserv. 58: 297-316.

GIBSON C.W.D., WATT T.A., BROWN V.K. 1987. The use of sheep grazing to recreate species-rich grassland from abandoned arable land. Biol. Conserv. 42: 165-183.

GRIME J.P., BROWN V.K., THOMPSON K., MASTERS G.J., HILLIER S.H., CLARKE I.P., ASKEW A.P., CORKER D., KIELTY J.P. 2000. The response of two contrasting limestone grasslands to simulated climate change. Science 289: 762-765.

HUTCHINGS M.J., BOOTH K.D. 1996. Studies on the feasibility of re-creating chalk grassland vegetation on ex-arable land. II. Germination and early survivorship of seedlings under different management regimes. J. Appl. Ecol. 33: 1182-1190.

JENSEN K., SCHRAUTZER J. 1999. Consequences of abandonment for a regional fen flora and mechanisms of successional change. Appl. Veg. Sci. 2: 79-88.

KAHMEN S., POSCHLOD P. 2004. Plant functional trait responses to grassland succession over 25 years. J. Veg. Sci. 15: 21-32.

KALAMEES R., ZOBEL M. 2002. The role of the seed bank in gap regeneration in a calcareous grassland community. Ecology 83: 1017-1025.

KOLLMANN J., POSCHLOD P. 1997. Population processes at the grassland-scrub interface. Phytocoenologia 27: 235-256.

KUPFERSCHMID A.D., STAMPFLI A., NEWBERY D.M. 2000. Dispersal and microsite limitation in an abandoned calcareous grassland of the southern Prealps. Folia Geobot. 35: 125-141.

MEDWECKA-KORNAŚ A., KORNAŚ J. 1966. Associations of steppes and dry grasslands. In: The vegetation of Poland. Szafer W. (ed.). Pergamon Press, PWN, Oxford, Warszawa, pp. 361-377.

MICHALIK S., ZARZYCKI K. 1995. Management of xerothermic grasslands in Poland: botanical approach. Colloques Phytosoc. 24: 881-895.

MILBERG P. 1995. Soil seed bank after eighteen years of succession from grassland to forest. Oikos 72: 3-13.

MITCHLEY J., WILLEMS J.H. 1995. Vertical canopy structure of Dutch chalk grasslands in relation to their management. Vegetatio 117: 17-27.

MORECROFT M.D., MASTERS G.J., BROWN V.K., CLARKE I.P., TAYLOR M.E., WHITEHOUSE A.T. 2004. Changing precipitation patterns alter plant community dynamics and succession in an ex-arable grassland. Funct. Ecol. 18: 648-655.

MORTIMER S.R., HOLLIER J.A., BROWN V.K. 1998. Interactions between plant and insect diversity in the restoration of lowland calcareous grasslands in southern Britain. Appl. Veg. Sci 1: 101-114.

OBERDORFER E., MÜLLER T., KORNECK D., LIPPERT W., MARKGRAF-DANNENBERG I., PATZKE E., WEBER H.E. 1990. Pflanzensoziologische Exkursionsflora. Ulmer, Stuttgart.

PÄRTEL M., KALAMEES R., ZOBEL M., ROSÉN E. 1998. Restoration of species-rich limestone grassland communities from overgrown land: the importance of propagule availability. Ecological Engineering 10: 275-286.

POSCHLOD P., BONN S. 1998. Changing dispersal processes in the central European landscape since the last ice age: an explanation for the actual decrease of plant species richness in different habitats? Acta Bot. Neerl. 47: 27-44.

POSCHLOD P., KIEFER S., TRÄNKLE U., FISCHER S., BONN S. 1998. Plant species richness in calcareous grasslands as affected by dispersability in space and time. Appl. Veg. Sci. 1: 75-90.

PRACH K., PYŠEK P. 1994. Clonal plants - what is their role in succession? Folia Geobot. Phytotax. 29: 307-320.
REJMÁNEK M., ROSÉN E. 1992. Influence of colonizing shrubs on species-area relationships in alvar plant communities. J. Veg. Sci. 3: 625-630.

ROSÉN E. 1988. Shrub expansion in alvar grasslands on Öland. Acta Phytogeogr. Suec. 76: 87-100.

ROSÉN E. 1995. Periodic droughts and long-term dynamics of alvar grassland vegetation on Öland, Sweden. Folia Geobot. Phytotax. 30: 131-140.

RUSCH G., FERNÁNDEZ-PALACIOS J.M. 1995. The influence of spatial heterogeneity on regeneration by seed in a limestone grassland. J. Veg. Sci. 6: 417-426.

SILVERTOWN J., DODD M.E., MCCONWAY K., POTTS J., CRAWLEY M. 1994. Rainfall, biomass variation, and community composition in the Park Grass Experiment. Ecology 75: 2430-2437.

STAMPFLI A., ZEITER M. 1999. Plant species decline due to abandonment of meadows cannot easily be reversed by mowing. A case study from the southern Alps. J. Veg. Sci. 10: 151-164.

STERNBERG M., BROWN V.K., MASTERS G.J., CLARKE I.P. 1999. Plant community dynamics in a calcareous grassland under climate change manipulations. Plant Ecol. 143: 29-37.

STÖCKLIN J., FISCHER M. 1999. Plants with longer-lived seeds have lower local extinction rates in grassland remnants 1950-1985. Oecologia 120: 539-543.

TER BRAAK C.J.F., ŚMILAUER P. 1998. CANOCO reference manual and user's guide to Canoco for Windows: Software for canonical community ordination (version 4). Microcomputer Power, Ithaca.

THEODORSSON-NORHEIM E. 1986. Kruskal-Wallis test: BASIC computer program to perform nonparametric one-way analysis of variance and multiple comparisons on ranks of several independent samples. Computer Methods and Programs in Biomedicine 23: 57-62.

TUTIN T.G., HEYWOOD V.H., BURGES N.A., MOORE D.M., VALENTINE D.H., WALTERS S.M., WEBB D.A. (eds). 1964-80. Flora Europaea. Vol. 1-5. Cambridge Univ. Press, Cambridge.

VAN SWAAY C.A.M. 2002. The importance of calcareous grasslands for butterflies in Europe. Biol. Conserv. 104: 315-318.

VAN TOOREN B.F. 1988. The fate of seeds after dispersal in chalk grassland: the role of the bryophyte layer. Oikos 53: 41$-48$.

VERKAAR H.J., SCHENKEVELD A.J., VAN DE KLASHORST M.P. 1983. The ecology of short-lived forbs in chalk grasslands: dispersal of seeds. New Phytol. 95: 335-344.

WALLISDEVRIES M.F., POSCHLOD P., WILLEMS J.H. 2002. Challenges for the conservation of calcareous grasslands in northwestern Europe: integrating the requirements of flora and fauna. Biol. Conserv. 104: 265-273.

WARD L.K., JENNINGS R.D. 1990. Succession of disturbed and undisturbed chalk grassland at Aston Rowant National Nature Reserve: dynamics of species changes. J. Appl. Ecol. 27: 897$-912$.

WILLEMS J.H. 1983. Species composition and above ground phytomass in chalk grassland with different management. Vegetatio 52: 171-180.

WILLEMS J.H., BIK L.P.M. 1998. Restoration of high species density in calcareous grassland: the role of seed rain and soil seed bank. Appl. Veg. Sci. 1: 91-100.

WILLEMS J.H., PEET R.K., BIK L. 1993. Changes in chalkgrassland structure and species richness resulting from selective nutrient additions. J. Veg. Sci. 4: 203-212.

ZOBEL M., OTSUS M., LIIRA J., MOORA M., MÖLS T. 2000. Is small-scale species richness limited by seed availability or microsite availability? Ecology 81: 3274-3282.

ZOBEL M., SUURKASK M., ROSÉN E., PÄRTEL M. 1996. The dynamics of species richness in an experimentally restored calcareous grassland. J. Veg. Sci. 7: 203-210. 